\title{
Person of the Issue: Melanie Klein (1882-1960)
}

\author{
Ankit Patel $^{1 *}$
}

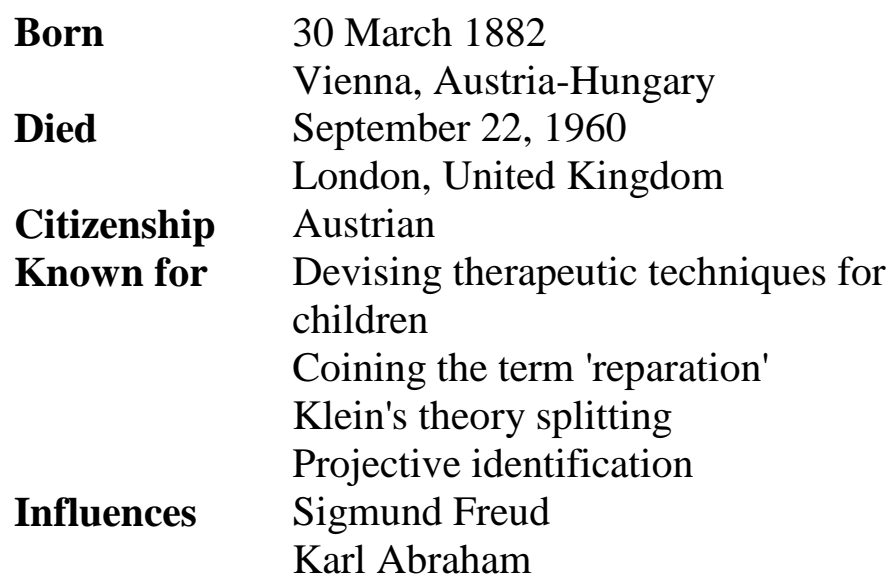

Influenced Herbert Rosenfeld

Otto F. Kernberg

Jacques Lacan

Cornelius Castoriadis

Donald Meltzer

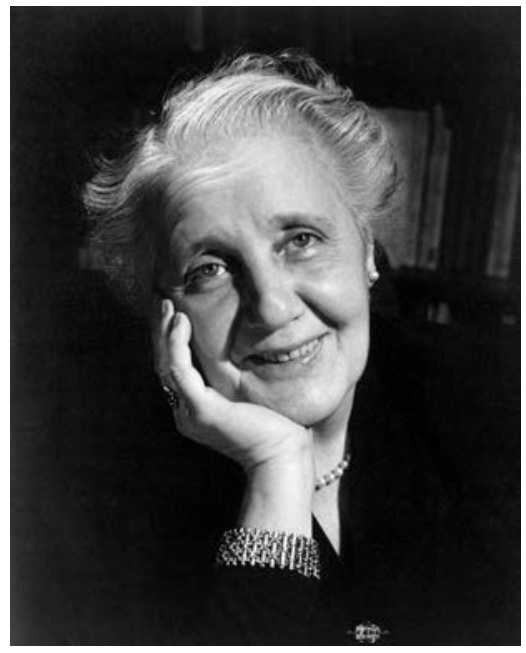

Melanie Klein was born on March 30, 1882, in Vienna, Austria. In 1903, she married Arthur Klein and relocated to Budapest. They had three children, born in 1904, 1907, and 1914.

Klein's first personal experience in the field of psychoanalysis began when she sought treatment for herself after her mother died in 1914. Earlier in her youth, Klein's siblings died: her brother died when she was 20, and her sister died when Klein was 4 years old. Klein was in treatment with Sandor Ferenczi between 1914 and 1917.

Klein was a pioneer in the treatment of children. She was among the first to use psychoanalysis on children and implemented several never-before implemented techniques and tools. She often used play and toys to help children discuss psychological issues.

Klein's approach to psychoanalysis conflicted with much of Sigmund Freud's work. Freud drew his ideas on child development from the recollections of his adult patients, but Klein worked directly with children and toddlers, giving her unique insight into the child development process. She defied Freud, arguing that the superego is actually present the moment a child is born,

\footnotetext{
${ }^{1}$ Clinical Psychology, Dept. of Psychology, Sardar Patel University, Vallabh Vidyanagar, Gujarat *Responding Author

(c) 2015 A Patel; licensee IJIP. This is an Open Access Research distributed under the terms of the Creative Commons Attribution License (http://creativecommons.org/licenses/by/2.0), which permits unrestricted use, distribution, and reproduction in any Medium, provided the original work is properly cited.
} 
preceding the Oedipal complex. Klein also claimed that a primitive form of the Oedipal complex was present much earlier in development than Freud claimed, as a child becomes preoccupied with overwhelming parental authority.

Her early work led her to certain clinical discoveries. For instance, she saw that the splitting appears very early as a mechanism in the child's mind, and that the mechanisms of projection and introjections accompanying the splitting result in the creation of a very complex internal world, even in a very small child. She saw the importance of early part-object relationships, already noticed by Abraham but never deeply investigated. As I have said, she had described both an earlier concept of the Oedipus complex and the roots of an early, very savage, superego connected with part-object introjections. But it was only with her description of the depressive position that Klein's early discoveries could be brought together to give a picture of the child's mental development.

However, there was yet another discovery to come, in the last years of her life. This is the discovery of the crucial importance of primitive envy, and this has become extremely controversial, even amongst some who agreed with Klein's theory of the two positions. It seems that the thought that envy could be early and primary, and directed from the start at the maternal breast, under the aegis of the death instinct, was an idea hard to tolerate. Envy is very connected with the pathology of the paranoid-schizoid position. Hatred attacks the bad object, but envy is directed at the ideal object, and interferes with the original splitting which enables the infant to have an ideal object, which is the basis of what in the depressive position becomes a more integrated good-and-bad object. Since it is the ideal object that is attacked in envy, it leads to a constant confusion between what is good and what is bad, and endless, often psychotic, confessional states. In the depressive position, excessive envy makes reparation very difficult, both because of the magnitude of the guilt, and because the object, once repaired, becomes again an object of envious attacks.

Since Klein, a great deal of work has been done by her pupils and followers on the transition between the paranoid and the depressive position, and the important role that is played in its pathology by the factor of envy.

\section{TIMELINE}

1882

- Melanie Reizes is born on 30th March at Tiefer Graben 8, Vienna to Moriz (aged 54) and Libussa Reizes (née Deutsch, aged thirty). Her father Moriz comes from an orthodox Jewish family from Lemberg, Galicia (now Lvov, Ukraine), and her mother from Warbotz, Slovakia. Moriz trained as a doctor against his very conservative family's wishes; Libussa is an intelligent, attractive young woman.

- Melanie is the last of four children, joining six-year-old Emilie, five-year-old Emmanuel, and four-year-old Sidonie. The family moved to Vienna from Deutschkreutz, Hungary (now Burgenland, Austria) sometime between 1878 and 1882.

1885

- When Melanie is three years old, Sigmund Freud, now 29, is in Paris studying hysteria and hypnosis with famous neurologist Jean-Martin Charcot. 
- Melanie's closest sister Sidonie dies of scrofula (tuberculous cervical lymphadenitis) at the age of eight. Melanie is four years old.

- Freud leaves Paris and returns to Vienna.

1887

- The Reizes family inherits a considerable sum of money on the death of Moriz's father. Melanie now five years old, the family moves from their second home in Vienna, a shabby fifth-floor apartment in Borsegasse, to a much larger, more elegant apartment in middle-class suburb Martinstrasse.

1891

- When Melanie is nine years old, 35-year-old Sigmund Freud moves to Berggasse 19, Vienna, his home and consulting rooms for the next 47 years.

1895

- In the same year as his last child Anna is born, Freud publishes his seminal Studies on Hysteria.

1898

- At the age of 16, Melanie already has her sights set on studying at the gymnasium. She has long wanted to study medicine, now specifically psychiatric medicine. This year she passes her entrance exams.

1899

- At the age of 17, Melanie meets her future husband, Arthur Stevan Klein, four years her elder and a second cousin. Klein is studying to be a chemical engineer in Zurich. He proposes to Melanie soon after their first meeting; she accepts. The engagement spells the end of Melanie's medical ambitions.

1900

- Melanie’s father, Moriz Reizes, dies on 6th April at the age of 72. On 25th December, her eldest sister Emilie marries Leo Pick, a young doctor.

- Freud publishes his fundamental work, The Interpretation of Dreams. Freud is to maintain throughout his life that it is his most important work of all. It forms the keystone of psychoanalytic thought and practice.

1901

- Melanie spends the summer with the Kleins in Rosenberg (in Slovakian Hungary, now northern Slovakia) while Arthur is in America.

- Freud publishes On Dreams, a text which will critically influence Klein's psychoanalytic thinking.

- Otto, Melanie's first nephew, is born to Emilie Pick on 16th October.

- Melanie returns home from Rosenberg around Christmas 1901.

1902

- On 1st December 1902 a second sibling, Melanie's adored older brother Emmanuel, dies in Genoa of heart failure, at the age of 25. His death comes after several years of aimless and indigent travelling around the Mediterranean. He has very probably been addicted to morphine and cocaine for some time, in addition to suffering from tuberculosis.

1903

- Still in mourning for her brother, Melanie Reizes marries Arthur Klein on 31st March, the day after her 21st birthday. They set up their home in Rosenberg.

- In May Melanie finds out she is pregnant. 
- Melanie, Arthur and one-year-old Melitta make a trip to the Adriatic coast, visiting a number of places including Trieste and Venice.

- Freud publishes Three Essays on the Theory of Sexuality.

1906

- In the spring, Melanie accompanies Arthur to an engineering congress in Rome.

- After four years of persevering with her friend Irma Schonfeld, Melanie finally sees the publication of a collection of Emmanuel's writing.

1907

- On 2nd March Melanie gives birth to her second child and first son, Hans, after suffering a deep depression during pregnancy.

- Late in 1907 the Kleins move to Krappitz, a small provincial town in upper Silesia (now Krapkowice, Poland), where Arthur has been appointed director of a paper mill. Libussa moves in soon afterward.

1908

- Melanie becomes increasingly anxious and depressed, clearly very unhappy in her married life in this small, friendless town. She is often away, visiting friends and family, and making trips to Budapest and Abbazia. She receives treatment - such as carbonic acid baths - for her "nerves". As a result she spends long periods of time apart from her young children, not a little encouraged by her mother Libussa in a series of strange, guiltinducing and interfering letters.

- In this year Freud meets Hungarian pscyhoanalyst Sándor Ferenczi. The two men begin an important professional and personal relationship, recorded in more than 1,200 letters over their careers. Ferenczi is to have an enormous effect on Klein, as her analyst, supporter and friend.

1909

- In May, now severely depressed, Melanie visits a sanatorium in Chur, an alpine town in eastern Switzerland. In June she moves a little further south, to St Moritz, and is experiencing problems with her bladder. In a letter from her mother, there is a suggestion that Melanie might be afraid that she is pregnant, something that she dreads.

- In November the Kleins, with Libussa in tow, move to Svabhegy, a suburb of Budapest.

- Freud publishes his study of five-year-old 'Little Hans,' the first such analytic observation of a chlid. The analysis is carried out by the boy's father, as directed by Freud.

1910

- In the new scenery of Budapest, Melanie spends much of her time with Jolanthe Vágó, Arthur's sister, and Klara, Jolanthe's divorced sister-in-law. She is very close to these two women, especially Klara.

- Melanie spends the summer with Klara in Rügen, a resort to the north of Berlin on the Baltic Sea.

- Karl Abraham, close friend and colleague of Freud, establishes the Berlin Psychoanalytic Society. Abraham is later to analyse Klein, and to become a deeply important figure in her psychoanalytic thinking and emotional life.

1911

- In August the Kleins move to Rozsdamb, a more affluent area of Budapest. 
- Again Melanie spends her summer holiday in Rügen with Klara.

1912

- Melanie writes to her mother, who is staying temporarily in Vienna, that she is feeling better, in fact "quite healthy." She refers to a "treatment" she has been having, though she does not refer to its nature. It is likely psychological, perhaps even psychoanalytical.

1913

1914

- Around Christmas 1913, Klein finds she is again pregnant.

- After another deeply depressed pregnancy, Klein gives birth to her third and last child, Erich, on 1st July. Two weeks later, on the 28th July 1914, the First World War breaks out. Both Arthur Klein and Melanie's brother-in-law Leo Pick are subsequently called up.

- Klein begins analysis with Sándor Ferenczi, a Hungarian psychoanaylst intimate with Freud and instrumental in the growth of psychoanalysis. For the first time in Klein's life she is able to talk about her emotional experiences, and to be listened to by a highly intelligent, attentive, perceptive audience of one. This encounter with Ferenczi is nothing less than a watershed in her life.

- At some point in this year Klein reads Sigmund Freud's On Dreams ('Über den Traum,' 1901). She is immediately filled with huge excitement about the insights and possibilities revealed by Freud, and becomes devoted to psychoanalysis.

- In October Ferenczi is called up to serve as a doctor to the Hungarian Hussars, though he continues to be analysed by Freud by post. He carries out some analyses himself, both in the army and on return visits to Budapest.

- In late October the Kleins take Libussa to be x-rayed, following a severe loss of weight. Cancer is ruled out by the doctor. However, she rapidly develops bronchitis, and on 6th November Melanie Klein's mother is dead.

1916

- Arthur Klein is invalided back home with a leg wound. Ferenczi also returns to Budapest, having been transferred to a neurological hospital.

1917

- Freud's famous essay, 'Mourning and Melancholia' is published. Klein will later develop her radical ideas about manic-depressive states, as well as her seminal concept of the depressive position, out of Freud's account of aggression and guilt as central to the experience of the melancholic patient.

1918

- On 28th and 29th September, Melanie Klein attends the Fifth Psychoanalytic Congress at the Hungarian Academy of Sciences in Budapest. She hears Freud read his paper, 'Lines of Advance in Psychoanalytic Therapy,' which further fuels her fascination with psychoanalysis. This is almost certainly the first time Klein hears Freud read his work in person, and will be one of the only times. For Klein this is an extraordinary moment, as she comes face to face with the brilliant and deeply revered founder of psychoanalysis.

- Toward the end of the year the Austro-Hungarian Empire dissolves as its monarchy collapses. The First World War finally ends on the 11th November 1918, after over four years of fighting and millions of lives lost. 
- In July Klein presents her study of her five-year-old son Erich to the Hungarian Psychoanalytic Society; it is her first study of a child. She is soon afterward awarded membership.

- Arthur Klein leaves Budapest and his family for Sweden in autumn 1919, as the antiSemitic White Terror takes hold of Hungary. The Hungarian Psychoanalytic movement is all but destroyed by this ferocious counterrevolutionary anti-Semitism. Melanie also leaves Budapest, taking her three children to stay with Arthur's parents in Rosenberg. Besides the political turmoil, the Kleins' marriage is not working, and it is clear they are increasingly unhappy living together.

1920

- In September Klein attends the first International Congress since the war, held in The Hague. She meets Joan Riviere for the first time.

- Freud publishes Beyond the Pleasure Principle, in which he introduces the bold new idea of the 'death instinct.' This concept, controversial from its incipience, is to play a significant part in the development of Klein's theory, particularly with relation to sadism and ego-splitting in the young child.

1921

- At the beginning of 1921 Klein leaves her in-laws in Rosenburg and moves to Berlin. Other psychoanalysts have also left Hungary due to the intensifying anti-Semitic climate, including Sándor Rádo, Alexander, Schott and Balint.

- After a few weeks spent in a pension in Grunerwald, Klein moves to Cunostrasse, a drab and uninspiring area. She has Erich with her, now six years old. Melitta, aged 17, is finishing her studies in Budapest, and Hans, aged 14, is at boarding school.

1922

- Klein delivers another paper on early analysis at the 1922 International Congress. On the back of this and her paper of the previous year, she is made an Associate Member of the Berlin Society.

1923

- After being made a full member of the Berlin Psychoanalytic Society in February, Klein embarks upon her first child analysis. This marks the start of a bold new approach to analytic treatment and theory, and the start of Klein's career. This is only strengthened when Klein's paper, 'The Development of a Child,' is published by Ernest Jones in the International Journal of Psychoanalysis.

- The child Klein names 'Rita' in her notes enters analysis with her; she is only two and a half years old. In November Abraham, at that time supervising Klein's work, writes to Freud:

- "In the last few months Mrs Klein has skilfully conducted the psychoanalysis of a threeyear-old with good therapeutic results. The child presented a true picture of the basic depression that I postulated in close combination with oral erotism. The case offers amazing insights into instinctual life." (A Psycho-Analytic Dialogue, The Letters of Sigmund Freud and Karl Abraham, 1906-27 [Hogarth Press, 1965], p. 339)

- Meanwhile, in her personal life, Klein and her husband Arthur attempt reconciliation, moving into a large house built by Arthur on his return from Sweden, Auf dem Grat 19, Dahlem. 
- Eager to learn from one of the great pioneers of psychoanalysis, Klein asks Abraham to analyse her. She manages to persuade him, despite his reservations about analysing a Berlin colleague. At the beginning of 1924 her treatment begins.

- After several months of trying to repair their marriage, relations between Melanie and Arthur fail to improve. Melanie leaves her husband for good in April, shortly after her daughter Melitta's marriage to Walter Schmideberg, a Viennese doctor and family friend of the Freuds.

- Following this final breakup of her marriage, Klein moves into a pension at Augbwigerstrasse 17, where she struggles to keep custody of Erich against Arthur's opposition.Six months into Klein's new analysis, Alix Strachey arrives from England. She is to become a very important catalyst in the development of Klein's career.

- Klein begins several important analyses of children, notably those she refers to as 'Peter,' 'Ruth,' 'Trude,' and 'Erna' in her writings. An important paper based on these cases is presented to the Berlin Society on 12th December.

- A letter from Alix Strachey to her husband, outlining Klein's 1924 Berlin Society paper, stimulates great interest when read to the British Society on 7th January 1925. Klein subsequently plans to give a series of lectures in London, with the enthusiastic encouragement of Ernest Jones. The Stracheys are greatly supportive of Klein's visit, translating papers, tutoring her English, and preparing the ground in the British Society.

- During the spring Klein meets Chezkel Zvi Kloetzel, a married man and father of one, at her dance class. They begin what, at least for Klein, is a deeply affecting love affair.

- In July Klein goes to London for her lecture series, which is held at the house of Karin and Adrian Stephen (brother of Virginia Woolf) in Gordon Square. She gives two lectures per week for three weeks, to a fascinated audience. Klein meets Susan Isaacs, thus beginning an important and enduring professional and personal relationship.

- Alongside these exciting developments Klein also suffers a great loss. Abraham falls ill in May, deteriorating until he dies on Christmas Day. Klein has been in analysis with him for only a year and a half. She later describes the termination of her analysis and Abraham's death as 'very painful.'

1926

- The London Clinic for Psychoanalysis opens on 6th May, Freud's 70th birthday.

- In September, at the invitation of Ernest Jones, Klein moves to London. She breaks off with Kloetzel (though he is to visit her several times over the next few years). Klein begins analysis of Jones' wife and two children between 15th September and 4th October.

- On 17th November Klein gives a paper before the British Psychoanalytic Society on fiveyear-old 'Peter,' with reference to the castration complex and anal-sadistic phantasy.

- Klein's son Erich joins her on 27th December, three months after her arrival. Klein now has six patients in addition to the Jones family.

1927

- On 19th March Anna Freud addresses the Berlin Society on the subject of child analytic technique. Her presentation is a barely disguised attack on Melanie Klein's approach to psychoanalysis. In response, Ernest Jones organises a symposium for the British Society 
on the same subject. Sigmund Freud is unhappy with what he sees as an attack on his daughter and, perhaps by extension, himself.

- At the beginning of September Klein attends the Tenth International Congress, held in Innsbruck. She delivers her paper, 'Early Stages of the Oedipus Complex,' her most radical conceptual offering to date.

- Klein is elected a member of the British Psychoanalytical Society on 2nd October.

1928

- Melitta Schmideberg, Klein's eldest child and only daughter, comes to London after graduating from university in Berlin. Like her mother she is now pursuing a career in psychoanalysis, and by 1930 she is a member of the British Society. She moves in with her mother and brother Erich, while her husband Walter remains in Germany for a further four years.

1929

- Klein begins analysis of 'Dick,' a four-year-old boy, seemingly struggling with schizophrenia. His condition has since been re-described as infantile autism. This analysis and its ensuing published paper forms a key moment in Klein's development of her ideas about early psychosis and its relation to aggression and guilt.

1930

- On 5th February Klein presents a paper, 'The Importance of Symbol-Formation in the Development of the Ego' to the British Society. It forms a hugely important stage in her psychoanalytic thinking. In this seminal paper, Klein asserts that the child's capacity for symbol formation, and more broadly for the formulation of thought, are vital elements in the healthy development of the ego. This paper is truly innovative, and opened the way to a better understanding of psychotic states.

1931

- Klein takes on her first training analysand, Dr. W. Clifford M. Scott, a medical graduate from Toronto, Canada.

1932

- Klein's first major theoretical work, The Psychoanalysis of Children, is published simultaneously in English, by Hogarth Press (set up by Virginia and Leonard Woolf), and in German, by the Internationaler Psychoanalytischer Verlag. In it she lays the foundations for her later innovation of the paranoid-schizoid and depressive positions.

1933

- $\quad$ On 22nd May Sándor Ferenczi dies of pernicious anaemia, at the age of 59.

- Klein moves to 42 Clifton Hill, St. John's Wood. Paula Heimann, fleeing Nazi Germany, moves to London, and becomes Klein's secretary. She subsequently enters analysis with Klein.

- Melitta is elected member of the Institute of Psychoanalysis on 18th October. Previously an exponent of her mother's theoretical position, Melitta becomes increasingly antagonistic toward her, mounting regular, unsparing attacks against her ideas and method in Society meetings.

- Kloetzel moves to Palestine at the end of the year, as anti-Semitism rages ever more violently through Europe. Klein will never see him again.

1934

- At the beginning of the year Klein starts seeing Sylvia Payne once a week, for treatment of a bout of intense depression. 
- Melitta begins analysis with Edward Glover, after having been previously analysed by Ella Sharpe. They become close allies against Klein in the on-going British Society infighting.

- In April, Melanie's eldest son Hans dies when a path crumbles under him as he hikes through the Tatra Mountains. He is 27. Melanie does not attend the funeral, held in Budapest, apparently too devastated to make the journey.

- Klein reads the first version of her seminal paper, 'The Psychogenesis of ManicDepressive States' at the Lucerne Congress in August.

1935

- On 16th January Klein reads a reworked version of her 1934 Congress paper, 'A Contribution to the Psychogenesis of Manic-Depressive States,' to the British Society. The paper explains her radical, brilliant new concept, the depressive position.

- Donald Winnicott, a paediatrician and recently qualified psychoanalyst, begins analysis of Klein's youngest child Erich, at her request.

- In Germany on 15th September, the Nuremberg Laws are passed at the annual Nazi party rally. Jews are stripped of their citizenship, the right to hold influential professional positions, and the right to marry 'Aryans.'

1936

- In February Klein delivers her paper, 'Weaning,' as part of a lecture series open to the public at Caxton Hall. It will later be published as part of Love, Guilt and Reparation and Other Works 1921-1945.

1937

- On 19th March Melitta Schmideberg reads her paper, 'After the Analysis - Some Phantasies of Patients,' a searing attack on Kleinian analytic technique and theory.

- Klein goes into hospital in July, for an operation on her gall bladder. She writes 'Observations Following an Operation' afterward, detailing her emotional reactions to anaesthetic, surgery, and the return to childlike dependency.

- She spends August recuperating in Devon with Erich and his new wife, Judy.

- In September Klein takes a rare holiday in Italy.

- Klein and Joan Riviere jointly present 'Love, Guilt and Reparation,' based on a previous public lecture.

- Read Klein's 'Observations after an Operation'...

1938

- Emilie and Leo Pick, Klein's sister and brother-in-law, arrive in England as refugees from Nazi-annexed Vienna. They move into a flat around the corner from Klein.

- Sigmund and Anna Freud flee Vienna after the Nazis invade Austria in March. They arrive in London on 6th June. They are just a couple of a flood of refugee psychoanalysts fleeing Nazi Germany and Austria. The British Society is thus changed out of recognition.

- On the night of 9th-10th November, Nazi supporters and SA stormtroopers vandalise and destroy Jewish shops and synagogues across Germany and Austria, killing, beating and arresting Jews. This horrific pogrom will become known as Kristallnacht ('Night of Broken Glass'). 
- Early in the year the Internal Object (I.O.) Group is set up, at the suggestion of Eva Rosenfeld and Susan Isaacs, as a regular opportunity for the Kleinians to discuss and formulate their ideas for presentation to their opponents.

- On 8th March the British Psychoanalytical Society celebrates its 25th birthday at the Savoy (taking 1914 rather than 1919 as the date of inception, despite the abortive nature of the first attempt). Virginia and Leonard Woolf are among the guests, and Klein meets them for the first time.

- Arthur Klein dies in Sion, Switzerland, at the age of 61.

- On 3rd September Britain declares war against Germany.

- Klein moves to Cambridge temporarily, one of many fleeing the capital for fear of air raids.

- On 23rd September, three weeks after the outbreak of the Second World War, Sigmund Freud dies at the age of 83 after years of suffering with cancer of the jaw.

- Klein re-works 'Mourning and Its Relation to Manic-Depressive States' over the winter, a paper originally given at the 1938 Paris Congress.

- Klein's sister Emilie Pick dies in London in May, of lung cancer. Klein is not with her.

- At the end of June Klein leaves London for Pitlochry in Scotland, at the request of 'Dick's' parents. Meanwhile, in London, the Battle of Britain approaches, making the capital highly dangerous. She returns to London for Christmas, missing her grandson Michael and her work there.

- Edward Glover publishes An Investigation of the Technique of Psychoanalysis, a barely disguised attack on Klein and Kleinian thought.

1941

- By the new year Klein has four patients in Scotland, Dick and his brother, and two doctors. During her time in Pitlochry she keeps up a regular correspondence with Donald Winnicott, by now a close friend and ally.

- At the end of April Klein starts analysis of ten-year-old 'Richard,' whose "unusual" set of psychical difficulties prove rich food for thought. She is soon eager to write a book dedicated to this particular case.

- At the beginning of September Klein leaves Pitlochry and returns home to London.

- The first of the British Society's Extraordinary Meetings takes place on 25th February, after months and years of increasing discord and infighting among its members. They are heated and often venomously personal battles between the opposing groups in the Society - the Kleinians and Viennese Freudians - and they carry on until June. In meetings Anna Freud and Edward Glover attack Klein's legitimacy as a psychoanalyst, while Melitta Schmideberg attacks her mother with a seemingly blind rage, more personal than theoretical. It looks as though the Society may not survive this deeply divisive war of ideas and personalities.

- The first of the Controversial Discussions is held on 21st October. They are highly charged debates about the conflicting psychoanalytic theories threatening to break the Society down the middle. Klein and Anna Freud are the central opponents in the struggle. During this period Kleinian theory will be criticized vehemently, and even accused of not being psychoanalytic. 
1943

- Susan Isaacs' paper, 'The Nature and Function of Phantasy' (later published in Developments in Psychoanalysis) is distributed to members of the Society to be discussed on the 27th January as part of the Controversial Discussions. It is a key paper in the history of psychoanalysis, demonstrating Klein's concept of infantile phantasy as intimately related to, and sprung from, classical Freudian thought and therefore resolutely psychoanalytic. The paper forms the focus of discussion at every meeting until 19th May.

1944

- After a meeting on the 24th January, Edward Glover resigns from the British Society, declaring it no longer 'Freudian,' that is, psychoanalytic.

- On 16th February Klein takes part in the Discussions for the first time in person. She delivers the paper forming the focus of the last Controversial Discussion on 1st March, 'The Emotional Life of the Infant.'

- Hanna Segal enters analysis with Klein, around the same time as Herbert Rosenfeld. Both Segal and Rosenfeld will go on to develop and expand Kleinian theory, as they push the limits of psychoanalysis in their work with borderline-psychotic and psychotic patients.

1945

- Melitta Schmideberg leaves the UK, now separated from her husband Walter, and moves to New York. She will live there until 1961, working with adolescent delinquents.

- Klein spends August on a farm with her daughter-in-law Judy and grandchildren Michael and Diana.

1946

- On 4th December Klein gives her paper, 'Notes on Some Schizoid Mechanisms' to the British Society. This is one of the most important works of Klein's career, and a pivotal moment in psychoanalytic thought, as she details the concepts of ego-splitting and projective identification.

- After much debate within the British Society, the 'A' and 'B' groups, and what becomes known as the 'Middle Group', are at last established as an urgent means of resolving the on-going and irreconcilable differences between the Anna Freudians and Kleinians. The bitter arguments that have raged through the Society for years are now at least partly assuaged, and the Society looks like it will survive.

1947

- John Rickman, a British psychoanalyst who has been in analysis with Freud, Ferenczi and Klein, is elected president of the British Society. As a member of the 'Middle Group' - neither Anna Freudian nor Kleinian - Rickman's appointment is a deliberate effort to preserve neutral government of the Society.

1948

- Susan Isaacs dies of cancer on 12th October, at the age of 63.

1949

- At the sixteenth Psychoanalytic Congress in Zurich, Klein sees her daughter Melitta for the first time in four years. They do not speak.

1950

- Some rare, silent cine footage shows Melanie Klein walking in the garden of her home in Clifton Hill at about this time. The identity of the filmmaker, and of the gentleman who appears with Klein, are unknown. 
- In preparation for the celebration of Klein's 70th year, her colleagues and friends publish Developments in Psychoanalysis, including essays by Heimann, Isaacs, Riviere, Klein, and others.

- Klein’s former lover Chezkel Zvi Kloetzel dies on 27th October.

1952

- Ernest Jones organises a dinner at Kettner’s (29 Romilly St, Soho) to celebrate Klein’s 70th birthday.

- In photograph, clockwise from left: [sitting] Marion Milner, Sylvia Payne, Eric Klein, Roger Money-Kyrle, Clifford Scott, Paula Heimann, James Strachey, Gwen Evans, [unknown], Michael Balint, Judy Klein (wife of Eric Klein), [standing] Melanie Klein, Enest Jones, Herbert Rosenfeld, Joan Riviere, Donald Winnicott

1953

- After a period of illness and dizzy spells (and a brief spell in hospital), thought to be brought about by excessive tiredness and overwork, Klein sells her house at Clifton Hill and moves to a smaller flat at 20 Bracknell Gardens, West Hampstead.

- Klein begins work on her autobiography (never published). Professor Janet Sayers has transcribed and annotated the fragments contained in the Melanie Klein archive at the Wellcome Trust. Published in Psychoanalysis and History, 15(2), 2013: 127-663.

1954

- Walter Schmideberg, Klein's estranged son-in-law, dies of an ulcerous illness in Switzerland, by now long separated from his wife Melitta.

1955

- On 1st February Klein establishes the Melanie Klein Trust, something she has thought of doing for several years. She invites Wilfred Bion, Paula Heimann, Betty Joseph, Roger Money-Kyrle, and Hanna Segal to be trustees, and puts in $£ 600$ to get it going.

- New Directions in Psychoanalysis is published.

- Klein attends the Geneva Congress, held on 24th-25th July. On the first day, Klein delivers a paper, 'A Study of Envy and Gratitude.' It is among the most controversial of all Klein's papers, and elicits a heatedly critical reaction. Paula Heimann, by now no longer on good terms with Klein, is among those critical of the paper's assertions.

- On 24th November Klein writes to Heimann, asking her to resign as trustee of the newly established Melanie Klein Trust. Spelling the end of their long and close friendship, Heimann soon after also leaves the Kleinian group.

1956

- Klein, with the help of previous analysand Elliott Jaques, starts to sort through and order her notes on Richard. These notes will become Narrative of a Child Analysis, her only full-length account of a single analysis.

1957

- On 6th May the Society marks Freud's centenary year.

- The highly controversial Envy and Gratitude is published in June, expanded from Klein's 1955 Geneva Congress paper with the help of Elliot Jacques.

- On her 75th birthday, Klein is given a Victorian garnet and gold set of jewellery by the British Society.

1958

- $\quad$ Ernest Jones dies on the 11th February, at the age of 79. 
- Listen to a recording of Melanie Klein's voice made at around this time.

1959

- After previously being taken up and then unfinished by French psychoanalyst and philosopher Jacques Lacan, Klein's Psycho-Analysis of Children is finally published in a French translation by Françoise and Jean-Baptiste Boulanger.

- Klein reads her paper, 'Our Adult World and Its Roots in Infancy' to an audience of sociologists in London.

- Klein gives her paper, 'On the Sense of Loneliness' at the Copenhagen Congress in July. In it she explores the yearning for an unattainable return to the baby's first experience of an entirely devoted mother figure. The paper will later be published as part of Envy and Gratitude and Other Works 1946-1963.

1960

- In the spring Klein is diagnosed with anaemia, and is increasingly exhausted and physically weak.

- During the summer Klein goes to Switzerland, to Villars-sur-Ollon, determined to regain her health. Her son Eric joins her, but by this time she has grown dangerously ill. She returns to England and is immediately taken to hospital. Colon cancer is diagnosed and Klein has an operation at the start of September. The operation seems at first to have been successful, but complications arise after she falls out of bed and breaks a hip. Melanie Klein dies on 22nd September.

- She is cremated at Golders Green Crematorium, her funeral attended by many friends and colleagues. Melitta is not there.

\section{QUOTES}

"One of the many interesting and surprising experiences of the beginner in child analysis is to find in even very young children a capacity for insight which is often far greater than that of adults. "

\section{REFERENCES}

About Health,

(2015) Melanie Klein

Biography,

reserved from http://psychology.about.com/od/profilesofmajorthinkers/p/klein_bio.htm

Dr Hanna Segal, the Romanian edition of The Writings of Melanie Klein in four volumes. Reprinted with permission of Esf Publishers, Binghamton, New York

GoodTherapy.Org, Melanie Klein (1882-1960) Reserved from http://www.goodtherapy.org/famous-psychologists/melanie-klein.html

Hinshelwood, Robert. (2005). Melanie Klein-Reizes. International Dictionary of Psychoanalysis. Biography In Context. Retrieved from http://www.gale.cengage.com/InContext/bio.htm

Mason, A. (2003). Melanie Klein; 1882-1960. The American Journal of Psychiatry, 160(2), 241. Retrieved from http://search.proquest.com/docview/220484768?accountid=1229

Melanie Klein Trust, (2015), Melanie Klein, Reserved from, http://www.melanie-kleintrust.org.uk/home

Vatli.Chat, (2015), Melanie Klein, Reserved from http://vatlin.chat.ru/Klein_biography_eng.htm

Photo Credit by: Wikipedia.Org 